\author{
Piotr POKORSKI ${ }^{1}$ \\ Piotr RADZISZEWSKI ${ }^{2}$ \\ Michat SARNOWSKI ${ }^{3}$
}

\title{
ODPORNOŚĆ NA DEFORMACJE TRWAŁE ASFALTOWYCH NAWIERZCHNI MOSTOWYCH
}

\begin{abstract}
Jednym z elementów, który decyduje o trwałości obiektu mostowego jest jego nawierzchnia. Jest ona narażona zarówno na obciążenia od przejeżdżających pojazdów, jak również na zmienne warunki atmosferyczne, naprężenia i odkształcenia przejmowane od płyty pomostu. W artykule przedstawiono problematykę związaną $\mathrm{z}$ oceną odporności na deformacje trwałe nawierzchni na obiektach inżynierskich. Przedstawione zostały metody badawcze oraz wyniki badań odporności na deformacje trwałe różnego typu mieszanek mineralno-asfaltowych stosowanych w konstrukcji nawierzchni mostowej. Oprócz zastosowanych w pracy standardowych metod pomiarowych, zaproponowana została ocena odporności na deformacje trwałe poprzez koleinowanie całych pakietów konstrukcji nawierzchni mostowej. Taka metoda pozwala na prawidłową ocenę warstw ochronnych charakteryzujących się dużą szczelnością. Plan badań obejmował zarówno typowe jak i nowe rozwiązania materiałowo-technologiczne. Porównano odporność na koleinowanie pakietów warstw nawierzchni ze względu na rodzaj zastosowanej mieszanki mineralno-asfaltowej w dolnej warstwie nawierzchni.
\end{abstract}

Słowa kluczowe: nawierzchnie mostowe, odporność na deformacje trwałe, mieszanki mineralno-asfaltowe

\section{Wprowadzenie}

Mosty stanowią integralną część drogowych ciągów komunikacyjnych i powinny charakteryzować się wysoką trwałością. Nawierzchnia mostowa ma duży wpływ na trwałość całego obiektu. Jest ona narażona na duże i szybkie

${ }^{1}$ Autor do korespondencji/corresponding author: Piotr Pokorski, Zespół Technologii Materiałów i Nawierzchni Drogowych, Instytut Dróg i Mostów, Wydział Inżynierii Lądowej, Politechnika Warszawska, Al. Armii Ludowej 16, 00-637 Warszawa, tel. 2223464 61, p.pokorski@il.pw.edu.pl

2 Piotr Radziszewski, Zespół Technologii Materiałów i Nawierzchni Drogowych, Instytut Dróg i Mostów, Wydział Inżynierii Lądowej, Politechnika Warszawska, Al. Armii Ludowej 16, 00-637 Warszawa, tel. 2223464 72, p.radziszewski@il.pw.edu.pl

${ }^{3}$ Michał Sarnowski, Zespół Technologii Materiałów i Nawierzchni Drogowych, Instytut Dróg i Mostów, Wydział Inżynierii Lądowej, Politechnika Warszawska, Al. Armii Ludowej 16, 00-637 Warszawa, tel. 2223464 61, m.sarnowski@il.pw.edu.pl 
zmiany temperatury $[1,2]$. Poza zasadniczymi funkcjami, które powinna spełniać nawierzchnia (rozkład obciążeń na pomost, zapewnienie przyczepności do podłoża, równość, szorstkość, odporność na ścieranie i powstawanie kolein) [3, 4], powinna ona zapewnić ochronę pomostu przed destrukcyjnym wpływem wody oraz stosowanych w okresie zimowym środków odladzających [1]. Brak uszkodzeń jest warunkiem koniecznym do zapewnienia odpowiedniej szczelności i trwałości nawierzchni mostowej.

Nawierzchnie asfaltowe na obiektach mostowych składają się z warstwy ścieralnej i ochronnej ułożonych na izolacji. Ze względu na zapewnienie szczelności nawierzchni, w mostowych mieszankach mineralno-asfaltowych, szczególnie przeznaczonych do dolnych warstw ochronnych, stosuje się wysoką zawartość asfaltu. Na sztywnych betonowych pomostach obiektów mostowych trwałość nawierzchni w dużej mierze zależy od odporności na deformacje trwałe.

Zwiększona zawartość lepiszcza oraz specyficzne warunki pracy nawierzchni mostowej mogą powodować powstawianie deformacji trwałych w postaci kolein.

W celu oceny odporności na odkształcenia trwałe mostowych systemów nawierzchniowych proponuje się wprowadzenie badania laboratoryjnego całego pakietu warstw, który w dobrym stopniu symuluje pracę nawierzchni na obiekcie mostowym w warunkach ,in situ”.

\section{Charakterystyka badanych mieszanek mineralno-asfaltowych}

$\mathrm{Na}$ podstawie przeglądu stosowanych rozwiązań materiałowokonstrukcyjnych oraz wniosków z badań rozpoznawczych, do badań odporności na deformacje trwałe wybrano cztery mieszanki mineralno-asfaltowe [5,7]. Do warstwy ścieralnej zastosowana została mieszanka grysowo-mastyksowa SMA 8 z polimeroasfalt PmB 45/80-55, do warstwy ochronnej beton asfaltowy AC 11 $\mathrm{z}$ lepiszczem $\mathrm{PmB}$ 45/80-55, asfalt lany MA 11 z polimeroasfaltem PmB 25/55-60 oraz nowa mieszanka mastyks wysokogrysowy SMA-MA $8 \mathrm{z}$ polimeroasfaltem PmB 45/80-55. Mieszanki mineralno-asfaltowe zaprojektowano zgodnie z wymaganiami WT-2. Mieszanka SMA-MA, która jest nowym rozwiązaniem materiałowo-technologicznym przeznaczonym do dolnych warstw nawierzchni oraz do izolacji obiektów mostowych, zaprojektowana została zgodnie z wymaganiami jak dla mieszanki SMA ze zmniejszoną zawartością wolnych przestrzeni. Dzięki temu charakteryzuje się ona rozbudowanym szkieletem grysowym oraz wysoką zawartością lepiszcza (około 8,5-9,0\% m/m). Tak dobrany skład mieszanki powoduje jej dużą szczelność (zawartość wolnych przestrzeni około $0,5-0,8 \% \mathrm{~m} / \mathrm{m}$ ) oraz dobrą odporność na deformacje trwałe $[5,6,7]$.

\section{Metodyka badawcza}

Obowiązujące w kraju dokumenty techniczne w sposób jednoznaczny opisują procedury określenia odporności na deformacje trwałe mieszanek mineral- 
no-asfaltowych. Podstawowym rodzajem badania jest koleinowanie w małym koleinomierzu wg PN-EN 12697-22. Dla mieszanki asfalt lany MA wymagania dotyczą odporności przy zastosowaniu metody penetracji stemplem wg PN-EN 12697-20. W celu oceny odporności na deformacje trwałe nawierzchni mostowych, w planie badań uwzględniono dodatkowo pomiar metodą koleinowania pakietu warstw oraz cyklicznego jednoosiowego ściskania (pełzanie pod obciążeniem dynamicznym) wg PN-EN 12697-25.

Metoda badania w małym koleinomierzu w powietrzu polega na koleinowaniu pojedynczej warstwy mieszanki mineralno-asfaltowej kołem obciążeniowym aż do momentu osiągnięcia 20000 przejazdów lub głębokości koleiny $20 \mathrm{~mm}$ w temperaturze $60^{\circ} \mathrm{C}$. Po zakończeniu badania obliczone zostają wymagane parametry zgodnie z normą PN-EN 12697-22: proporcjonalna głębokość koleiny

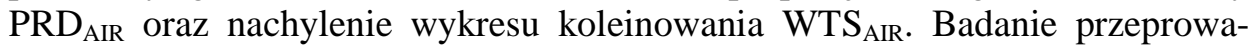
dzono na dwóch płytach każdego rodzaju mieszanki mineralno-asfaltowej.

W artykule zaprezentowano zmodyfikowaną metodykę oceny odporności na deformacje trwałe poprzez badanie koleinowania pakietu warstw. W pierwszym etapie badań oceniono oddzielnie poszczególne warstwy o grubości $4 \mathrm{~cm}$ a następnie pakiet asfaltowych warstw nawierzchni mostowej o łącznej grubości $8 \mathrm{~cm}$. Warianty badanych pakietów warstw przedstawione zostały na rys. 1. Płyty przygotowane do badania odporności na deformacje trwałe w koleinomierzu przedstawiono na rys. 2.
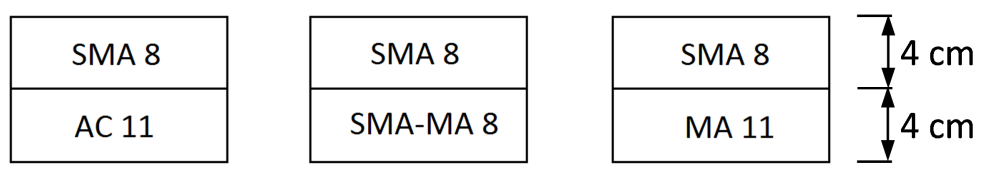

Rys. 1. Pakiety konstrukcji nawierzchni mostowych

Fig. 1. Packages of asphalt pavement deck construction

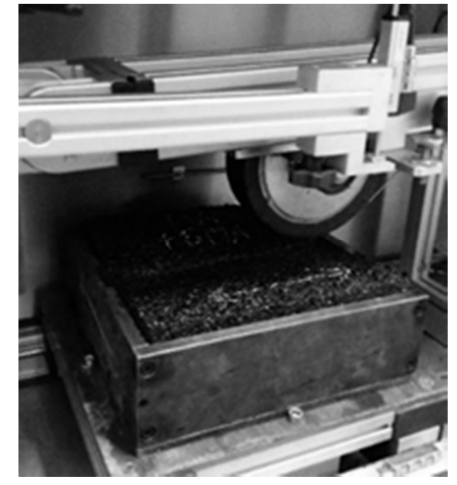

Rys. 2. Badanie próbki w koleinomierzu

Fig. 2. Sample in the wheel tracking device

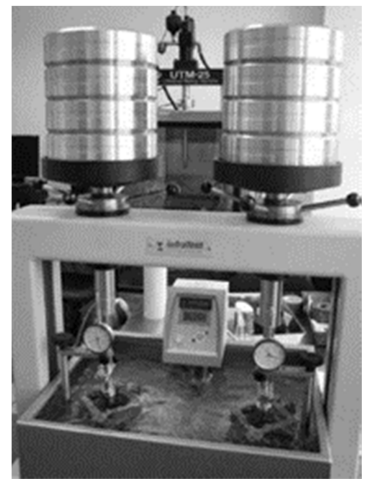

Rys. 3. Aparat do pomiaru penetracji stemplem

Fig. 3. The asphalt indentation penetrometer 
Badanie odporności mieszanek mineralno-asfaltowych na deformacje trwałe metodą penetracji stemplem polega na oddziaływaniu na próbkę stałym obciążeniem przez 60 min w temperaturze $40^{\circ} \mathrm{C}$. Rejestrowany jest przyrost zagłębienia stempla (trzpienia) w próbkę i na tej podstawie oblicza się zagłębienie trzpienia po 30 min (I) oraz przyrost zagłębienia między 30 a 60 min pomiaru $\left(\mathrm{I}_{\mathrm{nc}}\right)$. Badanie przeprowadzono równolegle na dwóch próbkach każdego rodzaju mieszanki. W badaniach laboratoryjnych tę metodę wykorzystano do określenia odporności na deformacje trwałe mieszanek z wysoką zawartością lepiszcza MA 11 oraz SMA-MA 8. Na rys. 3 przestawiono urządzenie do pomiaru penetracji stemplem.

Badanie odporności mieszanek mineralno-asfaltowych na deformacje trwałe metodą cyklicznego jednoosiowego ściskania polega na wielokrotnym powtarzalnym oddziaływaniu na próbkę naprężeniem o tej samej wartości. Badanie przeprowadzane jest w temperaturze $40^{\circ} \mathrm{C}$ i trwa ono 3600 cykli. Badanie przeprowadzono na pięciu próbkach każdego rodzaju mieszanki mineralnoasfaltowej. Wynikiem badania jest końcowe odkształcenie próbki oraz proporcjonalne nachylenie wykresu odkształcenia. Próbkę podczas badania przedstawiono na rys. 4.

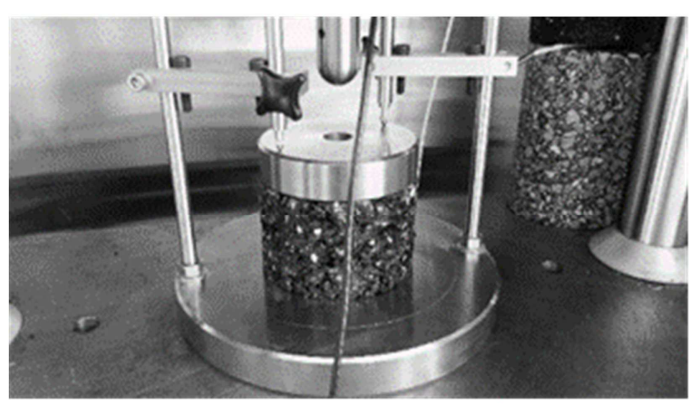

Rys. 4. Aparatura do badania jednoosiowego cyklicznego ściskania

Fig. 4. Cyclic compression test equipment

\section{Wyniki badań odporności na deformacje trwałe}

Wyniki badań odporności na deformacje trwałe mieszanek mineralnoasfaltowych określone $\mathrm{w}$ pojedynczej warstwie przedstawiono na rys. 5 . Z rysunku wynika, że najwyższą odpornością na deformacje trwałe charakteryzuje się mieszanka SMA 8 i mieszanka AC 11. Mieszanka SMA-MA 8 wykazuje właściwości pośrednie pomiędzy asfaltem lanym i mieszanką SMA. Badanie mieszanek SMA8, AC11 oraz SMA-MA8 przeprowadzono przy wymaganych 20000 przejazdów koła. Mieszanka typu MA 11 osiągnęła maksymalną dopuszczalną maksymalną głębokość koleiny 20 mm już po 1000 przejazdów. 


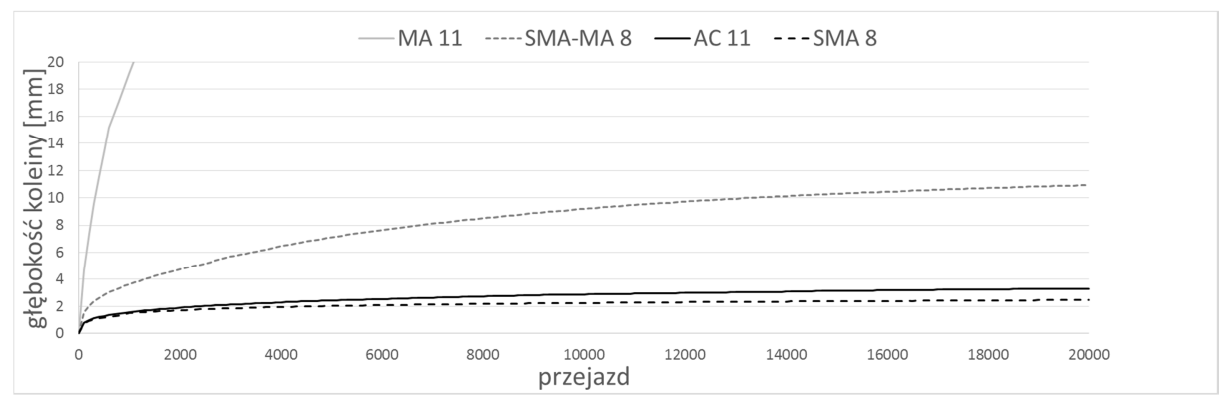

Rys. 5. Wykres badania koleinowania pojedynczych warstw

Fig. 5. Rutting single layers chart

Na rys. 6 przestawiono wyniki badania odporności na deformacje pakietów warstw asfaltowych. Konstrukcje, w których dolne warstwy stanowiły mieszanki AC 11 oraz SMA-MA 8 wykazały korzystną, podobną odporność na deformacje trwałe. Pakiet z mieszanką MA 11 osiągnął maksymalną dopuszczalną głębokość koleiny po 2500 przejazdów. Na rys. 7 przestawiono zdjęcia przeciętych pakietów płyt po koleinowaniu. W przypadku pakietów z mieszankami AC 11 i SMA-MA 8 deformacji uległa tylko górna warstwa z mieszanki SMA 8. W pakiecie z mieszanką MA 11 dużej deformacji uległa warstwa ochronna.

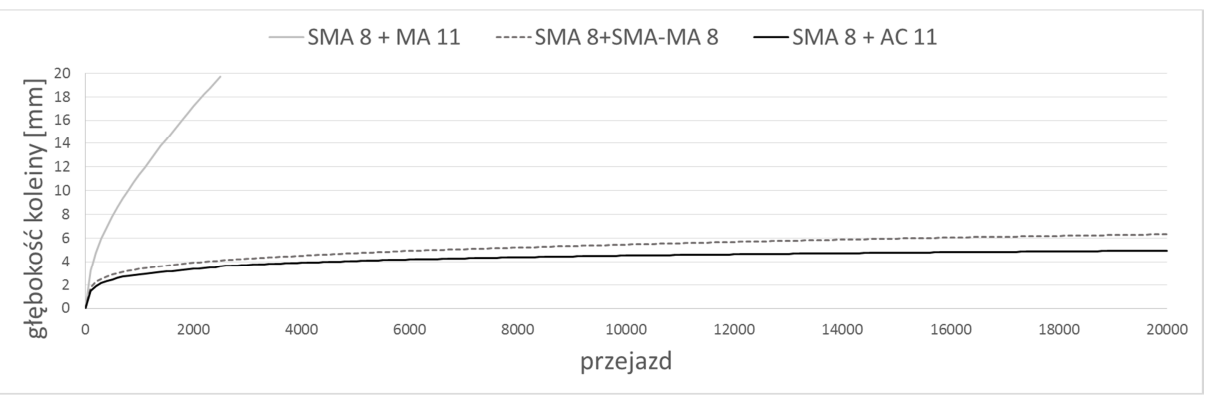

Rys. 6. Wykres badania koleinowania pakietów warstw

Fig. 6. Rutting package layers chart

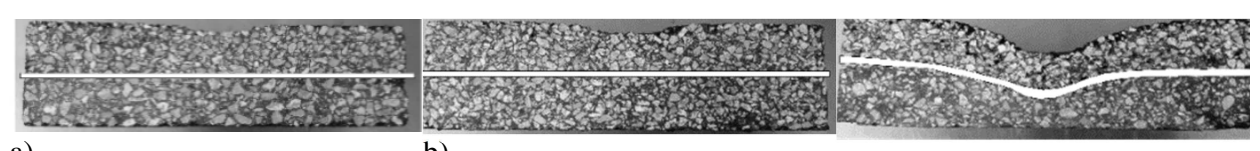

a)

b)

c)

Rys. 7.Przekroje poprzeczne pakietów warstw po badaniu koleinowania: a)SMA+AC, b) SMA+SMA-MA, c) SMA+MA

Fig. 7. Cross-section packages after wheel tracking test: a)SMA+AC, b) SMA+SMA-MA, c) SMA+MA 
Badanie odporności na deformacje trwałe metodą penetracji stemplem wykazało znacznie większą odporność mieszanki SMA-MA $8 \mathrm{w}$ porównaniu do mieszanki asfaltu lanego MA 11. Wyniki przedstawiono na rys. 8

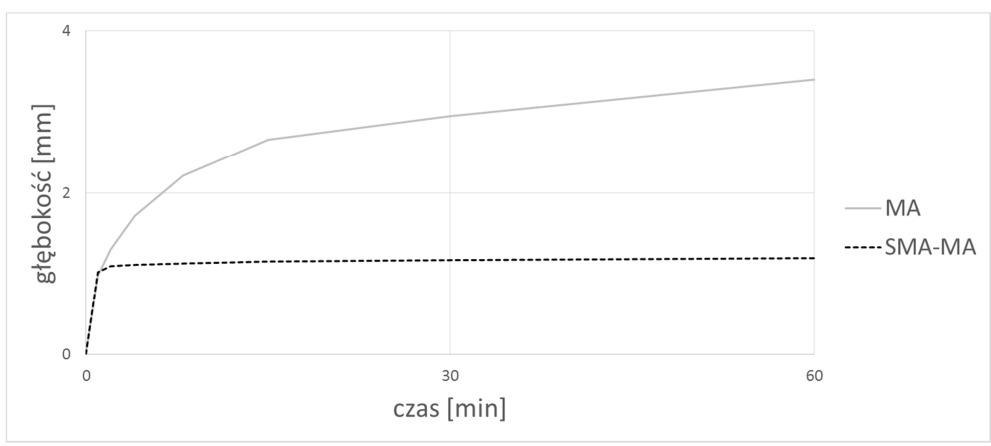

Rys. 8. Wyniki badania penetracji stempel

Fig. 8. Permanent deformation indentation results

Wszystkie mieszanki mineralno-asfaltowe poddane zostały także badaniu odporności na deformacje trwałe metodą cyklicznego jednoosiowego ściskania w pojedynczej warstwie. Na podstawie wyników badań przedstawionych na rys. 9 można stwierdzić, że najmniejszą odporność na powstawanie deformacji trwałych wykazał asfalt lany. Wyniki pełzania są zbieżne z wynikami otrzymanymi podczas badania w małym koleinomierzu (rys. 5).

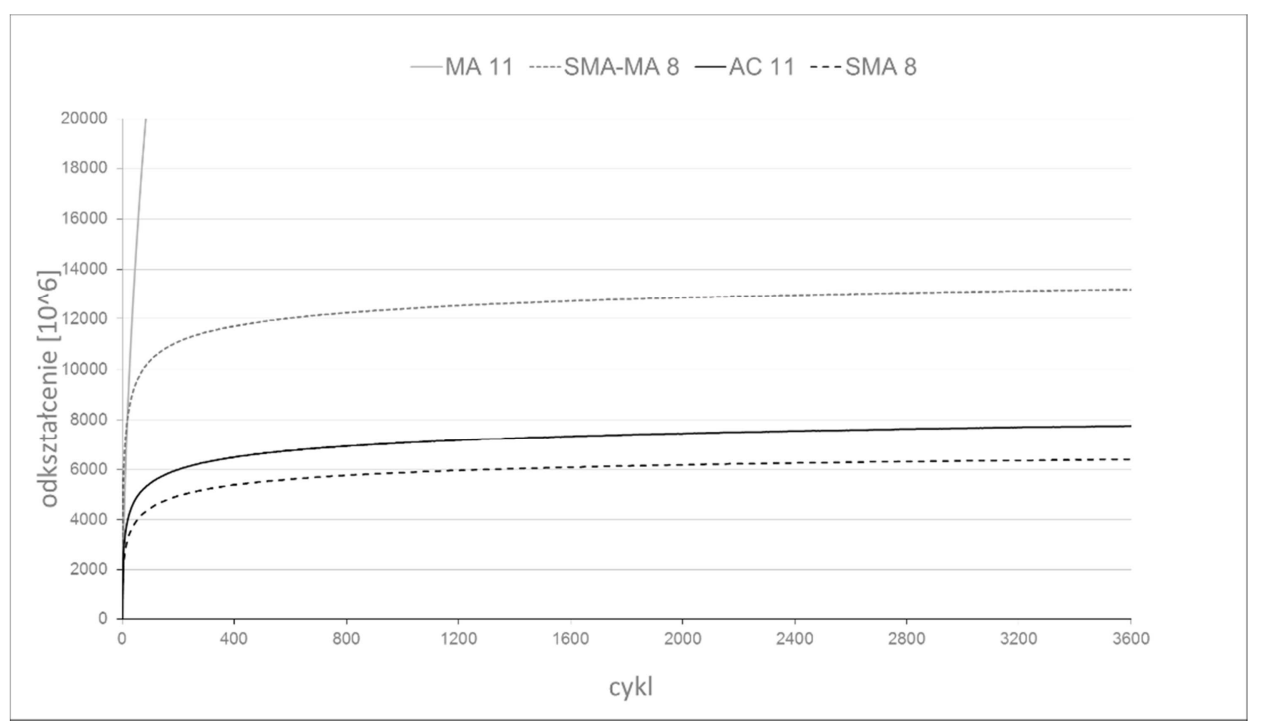

Rys. 9.Wyniki badania cyklicznego ściskania

Fig. 9. Cyclic compression test results 


\section{Podsumowanie}

W artykule przestawiono laboratoryjne procedury określania odporności na deformacje trwałe mieszanek mineralno-asfaltowych do nawierzchni mostowych. Analiza wyników badań koleinowania pojedynczych warstw i pakietów warstw nawierzchni wykazała zależność pomiędzy rodzajem zastosowanego typu mieszanki mineralno-asfaltowej, a odpornością na deformacje trwałe całej konstrukcji nawierzchni. Stwierdzono, że odporność na deformacje trwałe nawierzchni mostowych, charakteryzujących się zwiększoną zawartością lepiszcza należy badać w pakiecie warstw, co pozwala na ocenę w warunkach zbliżonych do rzeczywistych. Pod względem odporności na powstawanie deformacji trwałych zdecydowanie lepsze właściwości wykazały mieszanki grysowomastyksowe SMA-MA w porównaniu od mieszanki asfaltu lanego. Potwierdzono zależność pomiędzy wynikami badania odporności na deformacje trwałe oznaczanych metodą cyklicznego jednoosiowego ściskania (pełzania) i metodą koleinowania w powietrzu. Obydwie metody mogą być stosowane wymiennie. W celu pełnego potwierdzenia wyników badań otrzymanych metodą koleinowania, w przyszłości planuje się również ocenę pełzania pakietów warstw nawierzchni mostowych. Procedura badania koleinowania pakietu warstw nawierzchni w temperaturze $60^{\circ} \mathrm{C}$ oraz odporności na deformacje trwałe metodą cyklicznego ściskania w temperaturze $40^{\circ} \mathrm{C}$ i przy normowych warunkach obciążenia nie pozwala na prawidłową ocenę konstrukcji, w których wykorzystywana jest mieszanka asfaltu lanego.

\section{Literatura}

[1] Piłat J., Radziszewski P., Kowalski K.: Nawierzchnie asfaltowe i betonowe na obiektach mostowych. Seminarium „Nawierzchnie, izolacje i inne elementy wyposażenia mostów” Warszawa 2007, s. 49-52.

[2] Kilarski R.: Trwałość nawierzchni ma pomostach drogowych obiektów mostowych, Materiały Budowlane 4/2006, s. 86-89.

[3] Rozporządzenie Ministra Transportu i Gospodarki Morskiej w sprawie warunków technicznych, jakim powinny odpowiadać drogowe obiekty inżynierskie i ich usytuowanie, Dz.U. nr 63 poz 735, 2000.

[4] Madaj A., Wołowicki W.: Budowa i utrzymanie mostów, Wydawnictwo komunikacji i łączności, Warszawa 2001.

[5] Piłat J., Radziszewski P., Nawierzchnie asfaltowe, Wydawnictwo Komunikacji i Łączności, Warszawa, 2010.

[6] Mieczkowski P.: Warstwy ochronne z mieszanek mineralno-asfaltowych na obiektach mostowych. Izolacje nr 10/2013, s. 54-61.

[7] Radziszewski P., Piłat J., Sarnowski M., Kowalski K., Król J., Pokorski P., Liphardt A.: Rozwiązania materiałowo-technologiczne izolacji i nawierzchni obiektów mostowych, praca na zlecenie Generalnej Dyrekcji Dróg Krajowych i Autostrad, Warszawa 2013. 


\section{RESISTANCE TO PERMANENT DEFORMATION OF BRIDGE PAVEMENTS}

\section{S u m m a r y}

One of the elements that determines the durability of bridge structure is its pavement. It is exposed on the load of passing vehicles, changing weather conditions, stress and strain taken over from the deck. The article describes the problems associated with laboratory tests of resistance to permanent deformation of the pavement on engineering objects. Research methods and results of test of resistance to permanent deformation of different asphalt mixtures types were presented. In addition to the existing testing methods it has been proposed assessment of resistance to rutting whole bridge pavement packages. The research plan included typical and new technology and materials solutions. The rutting resistance of pavement packages with different type of bottom layer were compared.

Keywords: bridge pavement, resistance to permanent deformation, resistance, hot mix asphalt

Przestano do redakcji: 07.06.2016 $r$.

Przyjęto do druku: 30.06.2016 r.

DOI: $10.7862 /$ rb.2016.103 